\title{
Foreign Subsidiary Competitiveness: The Key to a Multinational Corporation’s (MNC) Global Growth
}

\author{
Yezdi H. Godiwalla \\ University of Wisconsin-Whitewater, Whitewater, USA
}

\begin{abstract}
A multinational corporation (MNC) should have its foreign subsidiaries become more competitive so that it can better compete globally and grow. Managing foreign subsidiary's competitiveness is vital for overall, long-term, and global organizational growth. Strategic global leadership, vision, and culture among the top managers of headquarters and foreign subsidiaries are vital for enabling the subsidiaries to pursue their vision of improved competitiveness. Sustained growth and improved competitiveness in the global organization's multiple country environments then become the means for an MNC's overall strategic enhancement.
\end{abstract}

Keywords: foreign subsidiaries’ competitiveness, MNC competitiveness, MNC growth strategies

\section{Introduction}

The global competitiveness of a multinational corporation (MNC) depends on the combined competitiveness of its foreign subsidiaries. The global competitiveness of an MNC should be an integral part of its overall long-term broad objectives, shorter-term detailed goals, and the overall global corporate strategy.

The long-term objectives, shorter-term goals, and corporate strategy, business strategy, and foreign subsidiaries' strategy of an organization should be derived from the organization's global vision and mission. The strategic management process begins with leadership of an MNC's top managers at headquarters and foreign subsidiaries. The process begins with strategic vision and mission, strategic analyses, choice of long-term objectives, shorter-term goals, and the formation, formulation, and implementation of corporate and foreign subsidiary strategies. It involves the leaderships at the MNC's headquarters and the foreign subsidiary units.

International management and strategic management are two important processes that need to be equally emphasized and their processes are to be skillfully combined. Strategic and visionary international leadership is a key to MNC global effectiveness. Its local, regional, and global competitiveness depends on it. It leads to sustained growth and profitability. Past organizational performance and current culture create an environment for change only if the strategic leadership can have a well-integrated global strategic plan (Wang \& Tran, 2012). Strategic international leadership focuses on the global plan for improving the overall organizational competitiveness, effectiveness, and growth. An important focus of such leadership is the management of the differences of culture and operating conditions across different countries.

Yezdi H. Godiwalla, professor, Management Department, College of Business and Economics, University of Wisconsin-Whitewater. Email: godiwaly@uww.edu. 


\section{Overall MNC Strategic Vision}

An MNC's global strategic vision and mission would drive the organization's global strategic management process. The global coordination of overall corporate strategy and the foreign subsidiaries' strategies would ensure an integrated global strategic management process. Such integration would ensure a combined organizational framework for pursuing global competitiveness. The global strategic management process has to be formal and systematic, starting with the macro-level issues (overall corporate objectives, goals, and strategy) and moving on to micro-level issues (subsidiaries' objectives, goals, and strategies).

The global industry dynamics and competition place considerable demands on an MNC. These demands can be in the form of improving value chain efficiency, product and process innovations and refinements, better strategic directions, better positing in the marketplace, and redefining the scope of its businesses and regions (Ecker, Van Triest, \& Williams, 2013).

It would be worthwhile that the MNC's headquarters leadership initiates a tentative or proposed (generally or broadly described) strategic vision, long-term goals, and a basic strategy, and then seeks active involvement from the foreign subsidiaries' executives for reshaping and refinement. It is important that the MNC's headquarters have a clear strategic vision for the MNC's future global position. It is more important that the vision be first developed in close collaboration with the leadership in the subsidiaries, thus enabling it to become a widely shared vision. What is desirable is a high level of commitment among the headquarters and subsidiaries' managers to a shared vision and strategy.

There are some aspects of strategic vision that are more worthwhile. Strategic vision is the desired or preferred form and posture of an organization in the future. The strategic vision of the key executives of the MNC's headquarters and foreign subsidiary units can be used to collectively transform the organization. It is a foresight of what should be the "ideal" for the organization. It assumes that the current constraint would not limit the future full realization of organizational potential in that it assumes that all the needed resources are possible (Want, 1993).

Strategic vision may appear to be out of a realistic reach or grasp of the organization, given its current capabilities, but that is all right. Hindle (1994, p. 42) defined strategic vision "as an irrational barrier-leaping ambition for a company". It becomes the flash point for future change. Higher vision can somewhat urge the people to strive harder. An intense strategic vision can be the driving force towards change.

\section{MNC Organizational Culture and Change}

There is a strong relationship among organizational strategy culture, structure, and technologies. Corporate strategy usually leads the change, or, the process of a new direction, and managers have to redirect the organizational culture, structure, and technologies. However, it is also conceivable that changes in culture and structure and innovations in technologies could also prompt changes in corporate strategy. For example, competitive onslaughts on an organization may evoke an appropriate response from culture in the form of reflex actions. Similarly, when technological innovations emanate from the within or from outside organization, the managers would modify the corporate strategy and foreign subsidiaries' strategies.

The effective strategic leadership at the foreign subsidiaries' level should focus on exploiting profitable opportunities in their host countries. Strategic vision and organizational culture are interrelated and vital in this context. Strategic vision must be matched by an appropriate organizational culture that would correctly channel 
the activities and resources of the organization (Griffith, Kiessling, \& Dabic, 2012; Karabell, 2010). It is important to see that changing an organization's strategy and culture should focus on a comprehensive approach that addresses all aspects of the organization, including research and development (R\&D) among the foreign subsidiaries (Ecker et al., 2013; Mezias, 2002; Kono, 1997; Schneider, Brief, \& Guzzo, 1996; Suutari \& Burch, 2001). Further, organizational culture itself can drive changes in corporate strategy (Morgan, 1993; Trice \& Beyer, 1993). This would be in addition to the sequence of strategy that could lead to changes in organizational culture.

The industry environment is another external environmental segment that can cause organizational culture changes, including changes emanating from competition, customers, channel distribution, technological innovation and applications from the same or another industry (Selmer \& Lauring, 2011). It is found that an organization usually tends to conform to the patterns of the industry to which it belongs (Chatman \& Jehn, 1994).

While the relationship between strategy and culture is such that they influence each other, organizational leaders may first conceive of a new strategy and change by designing the structure and culture so that they can realize the strategy (Deal \& Kennedy, 1983). They pursue organizational change by a planned design. In this way, strategy is viewed as the driving force that transforms the organization, its technologies, structure, and culture. And, they collectively change the posture of the organization (Finkelstein \& Hambrick, 1996).

Organizational leaders often use the organization as a means or an instrument to accomplish the goals that they impute upon the organization. This is referred to as the "instrumentality" of the organization. In as much, they view strategy, technologies, structure, and culture as more specific and detailed tools to carry out the goals that the leaders wish for the organization to accomplish. These are some of the issues of control and are vital to managers (Chang \& Taylor, 1999).

\section{Host Country's National Culture and Operating Conditions and the Foreign Subsidiary Unit's Organizational Culture and Operations}

Host country's national culture of a foreign subsidiary unit has a major impact upon the unit's organizational culture and cross-cultural communications and negotiations (Herbig, 1997). For example, the ethical content of a foreign subsidiary unit can be significantly influenced by the national culture of the host country, in addition to the MNC's headquarters' organizational culture (Robertson \& Fadil, 1999). These ideas can have an important impact on the discussions of the managers of the MNC's headquarters with the managers of the subsidiaries. The cultural differences can make the global strategic management process slower and complicated.

The foreign subsidiary unit has to address the often differing cultures of the MNC's headquarters, the MNC as a whole (including all the other units), and the national culture of the host country (Arrendondo, 1996; Harvey, Napier, Moeller, \& Williams, 2010; Shin, Morgeson, \& Campion, 2007). The growth of a foreign subsidiary unit would in part depend upon its organizational strategy and culture (Vachani, 1995). Since the unit exists in the context of the overall MNC as an organization, the local marketing environments, and the local national cultures, the unit has to strive to balance the often differing needs and expectations of these diverse groups. In this way, the unit is managing its stakeholders. 


\section{Host Country's Influences Upon a Foreign Unit’s Managerial and Leadership Styles}

Table 1 portrays some of the major factors that can influence a foreign unit's managerial leadership. The foreign unit's host country has a strong influence upon the unit. Most of the people of the unit are likely to be comprised of host country nationals. The national culture, economic, general, and particular industry factors of the host country provide an environment within which the foreign unit operates.

Table 1

Host Country's Influences Upon a Foreign Subsidiary's Managerial Leadership

\begin{tabular}{|c|c|c|}
\hline Host country’s cultural influence & Host country’s economic influence & Host industry-specific detail \\
\hline $\begin{array}{l}\text { 1.1. History of society, e.g., migrations, } \\
\text { dominations of and by other countries, life } \\
\text { style changes, material or livelihood } \\
\text { developments that change ways and } \\
\text { quality of life. } \\
\text { 1.2. Recent and projected migration } \\
\text { patterns and their impact on labor and } \\
\text { financial markets, political processes. } \\
\text { 1.3. Evolving values of society because of } \\
\text { migrations and other dynamics, impact on } \\
\text { society. }\end{array}$ & $\begin{array}{l}\text { 1.1. Natural resources, particularly as } \\
\text { they affect life styles and methods of } \\
\text { coping with life's challenges and other } \\
\text { issues. } \\
\text { 1.2. Plans for the development of natural } \\
\text { resources. } \\
\text { 1.3. Infrastructure of support facilities and } \\
\text { utilities, their quality and efficiencies. } \\
\text { 1.4. Financial institutions and } \\
\text { governmental regulatory supervision. } \\
\text { 1.5. Regional economics and impact on } \\
\text { the factories and markets. }\end{array}$ & $\begin{array}{l}\text { 1.1. Specific industry’s make-up. } \\
\text { 1.2. Industry structure, processes. } \\
\text { 1.3. Competition, competitors' } \\
\text { comparative strengths and weaknesses. } \\
\text { 1.4. Markets. } \\
\text { 1.5. Suppliers. } \\
\text { 1.6. Labor, professional, skilled, and } \\
\text { semi-skilled for various specialties. } \\
\text { 1.7. Customer groupings. } \\
\text { 1.8. Industry associations. } \\
\text { 1.9. Technological developments. }\end{array}$ \\
\hline $\begin{array}{l}\text { 2. Religions and beliefs, their influences } \\
\text { on social and workplace values, attitudes, } \\
\text { and behavior. }\end{array}$ & $\begin{array}{l}\text { 2.1. Component suppliers. } \\
\text { 2.2. Vendor suppliers. } \\
\text { 2.3. IT services. } \\
\text { 2.4. Utility and maintenance services. }\end{array}$ & $\begin{array}{l}\text { 2.1. Industry life cycle stage. } \\
\text { 2.2. Market leaders, runner ups, and } \\
\text { laggards. } \\
\text { 2.3. Relatedness with other industries. } \\
\text { 2.4. Industry growth rate. }\end{array}$ \\
\hline $\begin{array}{l}\text {, standard of living, quality of } \\
\text { towards one's job, company, } \\
\text { on. }\end{array}$ & $\begin{array}{l}\text { 3. Distribution system, wholesalers, } \\
\text { retailers, physical distribution, and } \\
\text { logistics. }\end{array}$ & $\begin{array}{l}\text { 3. Diversification strategies of the } \\
\text { multi-business groups, host country, and } \\
\text { foreign companies. }\end{array}$ \\
\hline $\begin{array}{l}\text { 4. Social structures and values, basis for } \\
\text { stratifying society: system of caste, class, } \\
\text { success, power/influence, money, land } \\
\text { ownership, and religious standing. }\end{array}$ & $\begin{array}{l}\text { 4.1. Communication and IT systems. } \\
\text { 4.2. Educational (general and } \\
\text { professional) and training standards and } \\
\text { patterns, and plans for improvements. }\end{array}$ & $\begin{array}{l}\text { 4. Entrepreneurial strategies and } \\
\text { prospecting activities, impacts on markets, } \\
\text { industries, and economy, governmental } \\
\text { industrial policies, and public policy, e.g., } \\
\text { market regulation. }\end{array}$ \\
\hline 5. Political and governmental influences. & $\begin{array}{|lccc|}\begin{array}{l}5 . \\
\text { disparities. }\end{array} & \text { Regional internal and external } \\
\end{array}$ & 5. Market share spreads, dominance. \\
\hline $\begin{array}{l}\text { 6. Sub-cultures in (internal and external) } \\
\text { regions and societal strata. }\end{array}$ & \begin{tabular}{|lcr} 
6. Governmental and regulatory \\
influences on business.
\end{tabular} & 6. Competitive advantages, innovations. \\
\hline $\begin{array}{l}\text { 7. Political, legal, and governmental } \\
\text { regulatory methods, law enforcement } \\
\text { intensity and effectiveness. }\end{array}$ & $\begin{array}{l}\text { 7.1. Capital formation, investors' attitudes } \\
\text { and motives, and investors and customers' } \\
\text { confidence. } \\
\text { 7.2. Financial regulation. }\end{array}$ & $\begin{array}{l}\text { 7. Organizational life cycle stages, } \\
\text { stage-specific strategies, and management } \\
\text { succession plans of direct competitors. }\end{array}$ \\
\hline $\begin{array}{l}\text { 8.1. Cultural impact on life style, valance, } \\
\text { and details. } \\
\text { 8.2. Social responsibility expectations } \\
\text { from organizations. }\end{array}$ & $\begin{array}{l}\text { 8. Labor markets, availability of skilled } \\
\text { technical and managerial people in } \\
\text { different specialties. }\end{array}$ & \\
\hline $\begin{array}{l}\text { 9. Dominant professional values among } \\
\text { local and foreign personnel. }\end{array}$ & $\begin{array}{l}\text { 9. Trade patterns and dependencies with } \\
\text { regional countries. }\end{array}$ & \\
\hline
\end{tabular}

The cultural environment of the host country can alter the preferred managerial leadership approach of an MNC's headquarters for its foreign subsidiary unit. The local customs and social approaches may make inviable the managerial leadership approaches of the MNC's headquarters. The economy of the host country provides general conditions within which the unit has to operate. Many of these are issues of infrastructure. The industry-specific factors include competition, customer groupings, industry associations and standards, suppliers, and labor. These affect the unit more immediately and directly. 
These three sets of host country factors (culture, economy, and specific industry) have a significant influence upon the unit's managerial leadership. These include the choice of decision-making styles, rationale for strategic decision-making, and approaches to further design and develop its organization (see Figure 1).

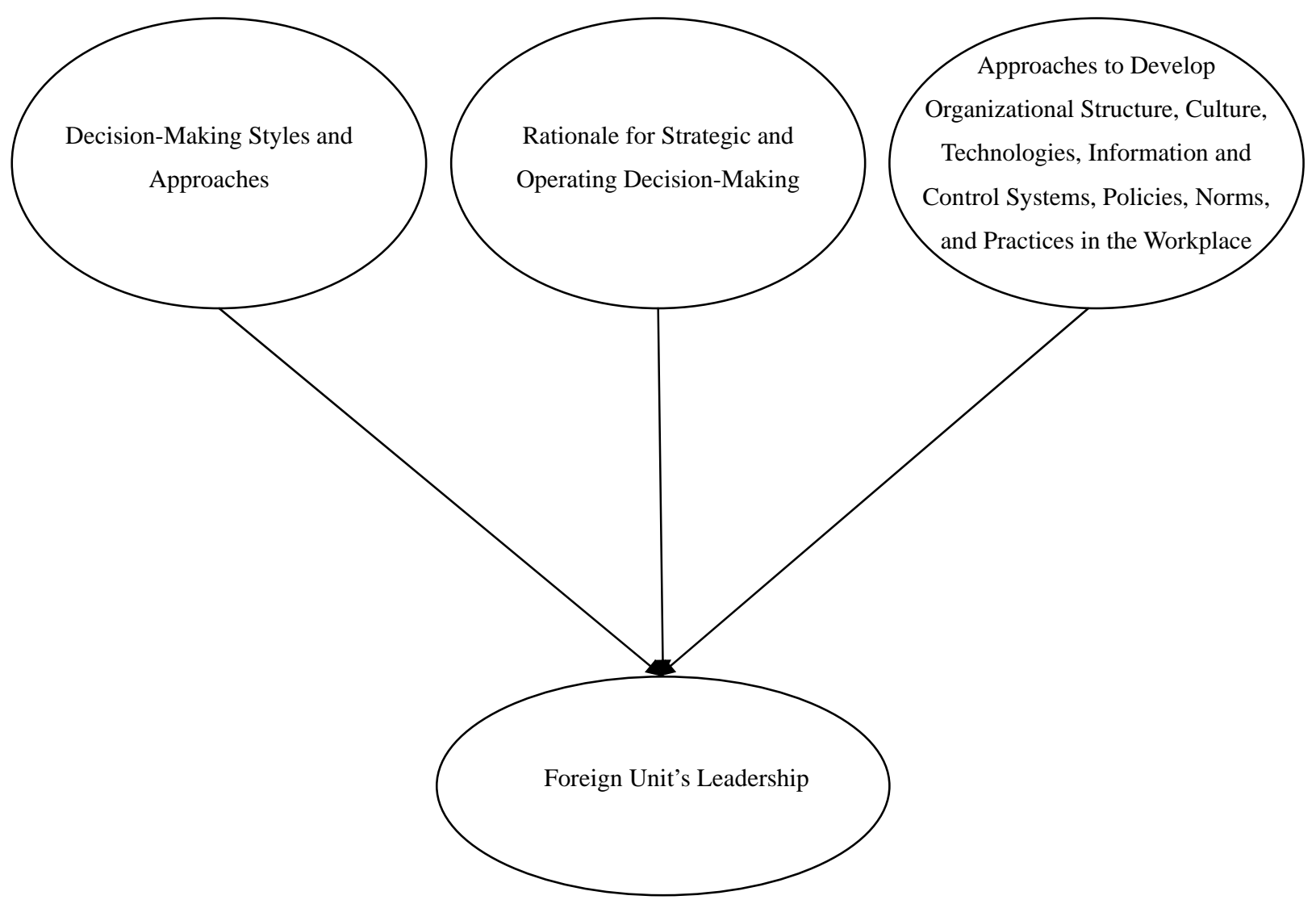

Figure 1. Foreign subsidiary leadership process.

\section{Matching Foreign Subsidiary Unit's Managerial Leadership Culture to Its Host Country's National Culture and Operating Conditions}

In a sense, MNCs are conglomerates even if they were to be in one line of business. This is because of their very diverse operating settings and cultural variations. They have to have a mindset of a conglomerate. That is to say, they should decentralize not only operating decision-making but also strategic decision-making (Lee \& Song, 2012; Muralidharan \& Phatak, 1999). They have to take another important step: decentralize managerial and decision-making styles. An MNC's headquarters must allow each of its foreign subsidiary units to formulate its own top management leadership style. Management is very culture bound. It is equally strongly felt at the top echelons as elsewhere (Pornpitakpan, 1999). An MNC's headquarters should not impose its own managerial culture to the units.

Table 2 provides an example of some different host country cultural, economic, and infrastructural conditions that may suggest a unit's appropriate managerial styles. This is a suggestive list, and each foreign subsidiary unit must analyze its host country's cultural, economic, and infrastructural environments so that it may evolve its own effective managerial culture and decision-making process. 
Table 2

Host Country's National Culture and Operating Conditions

\begin{tabular}{|l|l|l|}
\hline Foreign unit's host country's culture and environment & Foreign unit's appropriate leadership culture \\
\hline & $1 . \quad$ Foreign subsidiary unit's centralized strategic
\end{tabular}

1. Stable society, simple and stable economic decision-making, perpetuating bureaucracy with fixed job \begin{tabular}{l|l} 
structure, relative stability, and factors of dynamics. & descriptions, and clearly specified policies and operating
\end{tabular} processes.

2. Supportive and stable culture and technically advanced 2. Highly specialized and intensely trained institutionalized \begin{tabular}{l|l} 
environment. & managerial culture.
\end{tabular}

\begin{tabular}{|l|l|}
\hline 3. Technically specialized peer groups with focus on changing \\
\hline .
\end{tabular}

3. Technically advanced, changing environment. specific projects. Strategic semi-centralization, but significant operational decentralization.

4.1. Close team of top executives making bold and risky moves.

4. Turbulent, risky, erratic, and uncertain economic, political, 4.2. Quick monitoring and correcting the strategy and competitive environment. $\quad$ implementation process.

4.3. Strategic semi-centralization, but significant operational decentralization.

5.1. Closely knit top, middle, and bottom management, supervisory teams.

5. Complex cultural environment subject to changes (where no 5.2 . Quick monitoring and correcting the strategy clear comprehensive pattern emerges, nor an effective $\mid \begin{aligned} & \text { implementation process. } \\ & 5.3 \text {. Flexible, decentralized, and adaptive structure; }\end{aligned}$ managerial approach appears to be imminent). collaborative, problem-solving, and risk-taking culture. 5.4. Strategic semi-centralization, but significant operational decentralization.

Each of the five different host country's environments as mentioned in Table 2 is reviewed here. The effective management style depends upon the social conditions, pace of change, complexity of business decision-making environments, and structure of economy.

A foreign subsidiary unit's host country's culture and environment have a significant impact on how the subsidiary would operate. They influence its leadership and motivational styles. The culture and environment can have a broad range. The can range: (1) from a stable to turbulent environment; (2) from a simple to complex environment; (3) from a simple moonlight country culture to multi-tiered and complex culture; and (4) from a basic economic and technological infrastructure to a complex and advanced infrastructure.

The host country's culture and environment can influence the choice of the foreign subsidiary unit's organizational culture and leadership styles: (1) from centralized and rigid bureaucracy to decentralized and adaptive structure; and (2) from cautious and defensive approaches to entrepreneurial, exploring, and risk-taking approaches.

Host Environment 1. Stable society and simple and stable economy can have very centralized strategic decision-making. The decision parameters, scope, and rationale remain essentially the same even over a relatively longer period of time, and so the unit could centralize all major decisions at the top management. The foreign subsidiary unit can be run as a typical bureaucracy with specific job descriptions, and the detailed roles and tasks remain the same for a long time.

The management must first create a suitable and optimum organizational form and then staff it with capable people who can perpetuate the bureaucracy, carrying out the directives of the top and middle management. This would be a highly centralized decision-making structure. 
Host Environment 2. Supportive and stable culture and technically advanced environment enable the foreign subsidiary unit's top management to pursue a highly professional approach. Because of the stability, the organization can institutionalize the decision-making process. Top management approach is sophisticated and maintains a sense of permanence.

For many successful large organizations, its technological core is one of its key. It protects its core technological core. It has to be staffed by very competent people who continuously innovate and are evolving as capable and learning technical staff. The top management and the middle-level managers of the organization can pursue a semi-decentralized decision-making structure, except for technical core which would have a greater autonomy on technical issues.

Host Environment 3. This environment is different from the previous environments in that it is faster changing. Its change is somewhat linear, and not as erratic and turbulent as in the next two environments. The top management culture and decision-making style may be characterized by its specialized peer groups so that they can concentrate on technically intense activity. The changing nature requires shifts in focus, and so groups of peers focusing on important issues would characterize the top managerial mindset.

The technical staffs themselves have to be more innovative and also seek to complement externally generated innovations by substantial adaptations. The administrative structure must be responsive to the technically dynamic external environment.

Host Environment 4. The erratic and turbulent nature of this environment requires the top management to act often quite boldly, quickly (without spending too much time on problem research and analyses), and in unison. This means that the unit's top management must be close knit and loyal team players. They must know what and how each player thinks, decides, and acts in a diverse array of business, political, and people situations. The high risk nature demands that they should be great risk-takers and decisive players. An important trait of such a team should be that they should be willing to take/capable of taking some loss, should their risk-taking not work out.

The foreign subsidiary's leadership must be focused upon being pro-active and preventive to the dynamic political, social, and economic environments. It must pursue flexible strategies so as to take fuller advantage of the erratic and unpredictable external changes. It should not pursue "goal-lock" approaches, but instead, should keep its options flexible. It should pursue activities that make the organization's internal sub-systems (e.g., marketing, R\&D, operations) more agile, adaptive, and pro-active (Ecker et al., 2013). For example, it should pursue short-term, contingency planning rather than longer-term planning, thus making the organization more agile and adaptive focusing on developing better boundary spanning skills among its sub-systems that are in direct contact with their external sub-environments. It should pursue a more intensive scanning of the external sub-environments for shifts and non-linear, radical changes that can have an impact on the sub-systems of the organization. Because of the attendant high complexity and erratic nature and the rapid change rate of the external sub-environments, the organization should not have a rigid structure, but instead, should have a flexible structure with good internal communications and develop a higher capability of rapid mobilization of its internal resources to the locus of the organization's problem or opportunity areas.

Host Environment 5. This environment is characterized by unfathomable cause-effect relationships in the environment. When the unit's top management cannot decipher a consistent, effective decision-making rationale, then they have to adopt an experimenting approach. In this managerial decision-making style, the approaches are tentative. The managerial styles can be changing and evolving. 


\section{Conclusion}

An MNC's vision, mission, broadly stated long-term objectives, shorter-term and detailed goals, overall MNC corporate strategy, and foreign subsidiaries' strategies must be continuously evolving and adaptive. They must be responsive to the foreign subsidiaries' host countries' changing environments. Because of the MNC's diverse sectors of operations (for both geographical and industrial sectors), it may have to generate better alertness, agility, flexibility, and pro-active approaches.

It must have in place formal, systematic strategic management process through its global organization. Empowering its foreign subsidiaries to generate their own operating decision-making rationale and tactical planning in dealing with their respective local external environments would enable them to more freely focus on their task environments.

For the initial or starting phase, a "grass roots" (or bottom-up) approach (an approach emanating from the foreign subsidiaries), the MNC's corporate headquarters may develop the cumulative strategic choices and directions, and in doing so, shape the integrative global strategic intent. In doing so, it can formulate the long-term broad objectives, the short-term detailed goals, and the overall MNC corporate strategy.

With this "grass roots" (or bottom-up) approach, the headquarters may initiate a formal strategic management process consisting of: (1) overall MNC long-term corporate objectives, shorter-term goals, and overall MNC corporate strategy; (2) subsidiaries' (i.e., for each subsidiary) long-term objectives, shorter-term goals, and subsidiaries' corporate strategy; and (3) the next year's subsidiaries' budgets and specific programs.

By following the approach of first initiating "grass roots" (or bottom-up) communications, the headquarters would have an opportunity to understand the realities of the MNC's diverse environments. The headquarters can then propose a tentative broad picture for its overall MNC long-term objectives and overall MNC shorter-term goals. These would then be discussed by the headquarters and foreign subsidiaries, discussed and modified, until the headquarters and the foreign subsidiaries reach an agreement on the overall MNC objectives and goals.

As we consider each foreign subsidiary at a time, the matching of the managerial and leadership styles of a foreign subsidiary to the characteristics of its host country's national culture and operating environments is vital for the foreign subsidiary's effective performance. In this context, the host country's national culture presents a back drop for the subsidiary's organizational culture and the basis for its effective managerial and leadership styles. It would be beneficial for correctly adapting the foreign subsidiary's managerial and leadership styles and its organizational culture to correctly match the host country's national culture and operating conditions.

\section{References}

Arrendondo, P. (1996). Successful diversity management initiatives: A blueprint for planning and implementation. Thousand Oaks, CA: Sage Publications.

Chang, E., \& Taylor, M. S. (1999). Control in multinational corporations (MNCs): The case of Korean manufacturing subsidiaries. Journal of Management, 25(4), 541-565.

Chatman, J. A., \& Jehn, K. A. (1994). Assessing the relationship between industry characteristics and organizational culture: How different can you be. Academy of Management Journal, 37(3), 522-553.

Deal, T. E., \& Kennedy, A. A. (1983). Culture: A new look through old lenses. Journal of Applied Behavioral Science, 19(4), 498-505.

Ecker, B., Van Triest, S., \& Williams, C. (2013). Management control and the decentralization of R\&D. Journal of Management, 39(4), 906-927. 
Finkelstein, S., \& Hambrick, D. C. (1996). Strategic leadership: Top executives and their effects on organizations. Minneapolis, MN: West Publishing.

Griffith, D. A., Kiessling, T., \& Dabic, M. (2012). Aligning strategic orientation with local market conditions: Implications for subsidiary knowledge management. International Marketing Review, 29(4), 379-402.

Harvey, M., Napier, N. K., Moeller, M., \& Williams, L. A. (2010). Mentoring global dual-careers couples: A social learning perspective. Journal of Applied Social Psychology, 40(1), 212-240.

Herbig, P. (1997). External influences in the cross-cultural negotiation process. International Management and Data Systems, 97(4), 158-168.

Hindle, T. (1994). Field guide to strategy. Cambridge, MA: Harvard University Press.

Karabell, Z. (2010, August 2). With stocks, it's not the economy. Time, p. 20.

Kono, T. (1994). Changing a company's strategy and culture. Long Range Planning, 27(5), 85-97.

Lee, S. H., \& Song, S. (2012). Host country uncertainty, intra-MNC production shifts, and subsidiary performance. Strategic Management Journal, 33(11), 1331-1340.

Mezias, J. M. (2002). Identifying liabilities of foreignness and strategies to minimize their effects: The case of labor lawsuit judgments in the United States. Strategic Management Journal, 23(3), 229-244.

Morgan, M. J. (1993). How corporate culture drives strategy? Long Range Planning, 26(2), 110-118.

Muralidharan, R., \& Phatak, A. (1999). International R\&D activity of US MNCs: An empirical study with implications for host government policy. Multinational Business Review, 7(2), 97-115.

Pornpitakpan, C. (1999). The effects of cultural adaptation on business relationships: Americans selling to Japanese and Thais. Journal of International Business Studies, 30(2), 317-337.

Robertson, C., \& Fadil, P. A. (1999). Ethical decision making in multinational organizations: A Culture-based model. Journal of Business Ethics, 19(4), 385-392.

Schneider, B., Brief, A. P., \& Guzzo, R. A. (1996). Creating a climate and culture for sustainable organizational change. Organizational Dynamics, 24(4), 7-19.

Selmer, J., \& Lauring, J. (2011). Expatriate academics: Job factors and work outcomes. International Journal of Manpower, 32(2), 194-210.

Shin, S. J., Morgeson, F. P., \& Campion, M. A. (2007). What you do depends on where you are: Understanding how domestic and expatriate work requirements depend upon cultural context. Journal of International Business Studies, 38(1), 64-83.

Suutari, V., \& Burch, D. (2001). The role of on-site training and support expatriation: Existing and necessary host-company practices. Career Development International (Bradford), 6(6), 298-312.

Trice, H. M., \& Beyer, J. M. (1993). Changing organizational cultures. In The cultures of work organizations (pp. 393-428). Upper Saddle River, NJ: Prentice Hall.

Vachani, S. (1995). Enhancing the obsolescing bargain theory: A longitudinal study of foreign ownership of U.S. and European multinationals. Journal of International Business Studies, 26(1), 159-180.

Wang, Y. L., \& Tran, E. (2012). Effects of cross-cultural and language training on expatriates' adjustment and job performance in Vietnam. Asia Pacific Journal of Human Resources, 50(3), 327-350.

Want, J. H. (1993). Managing radical change. Journal of Business Strategy, 14(3), 21-28. 